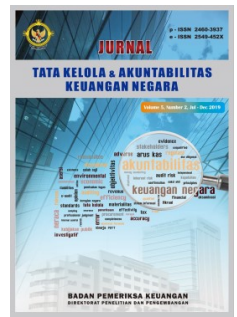

\title{
IMPLEMENTATION OF ROCK MINING POLICY AFTER LAW NUMBER 23 OF 2014 (STUDY OF ROCK MINING PERMIT IN SUBANG DISTRICT WEST JAVA PROVINCE)
}

\author{
Gede Suyasa ${ }^{1}$, Muchlis Hamdi ${ }^{2}$, Prio Teguh ${ }^{3}$, Megandaru ${ }^{4}$ \\ Institut Pemerintahan Dalam Negeri \\ suyasa76_2001@yahoo.co.id ${ }^{1}$ \\ muchlis.hamdi03@gmail.com² \\ prioteguh09@gmail.com ${ }^{3}$ \\ megandaru@gmail.com ${ }^{4}$
}

\begin{abstract}
The purpose of this study is to analyze and study the process of rock mining permit including the effectiveness and benefit from policy implementation related to the abolition of the authority of regency/city government in the rock mining activity after the enactment of Law Number 23 of 2014 in Subang Regency. The method used in this study is a qualitative method by interviewing parties related and literature review. The results of the study indicate that there are differences in the duration of the permit for rock mining due to differences in the process of issuing rock mining permits before and after the authority of the management of rock mining by the province. The social impact of the transfer of authority over the management of rock mining does not affect the surrounding community. This is due to the coordination and written agreements between the entrepreneur and the community related to the social responsibility management of the entrepreneur to the community.
\end{abstract}

\section{KEYWORDS:}

Policy; permits; rock mining; Law Number 23 of 2014

DOI: 10.28986/jtaken.v5i2.318 


\section{INTRODUCTION}

The enactment of Law Number 23 of 2014 concerning Local Government has shifted the paradigm of the management of mineral and coal resources to decentralization at the provincial level. This created problems because Law Number 4 of 2009 on Mineral and Coal Mining was drafted by Law Number 32 of 2004 on Local Government, (which has been replaced) with the paradigm of decentralization at the level of regency/city. This has created an asynchronously between the two regulations. However, in the course of implementation, the provincial government is vested with the authority to issue mining business permits if the government wishes to optimize the decentralization of authority of the provincial government as regulated in Law Number 23 of 2014 (Isnaeni, 2018). That disharmony posed legal uncertainty to the mining company which will affect the mining business climate of the community (Firmansyah \& Evendia, 2015).

The shift of the authority of the regency/city of local government to the provincial government in mining activities has caused mining permit procedures to complicate. This has posed an impact on the longer permit process meanwhile the needs of rock commodity at the local level cannot be postponed due to the type of rock is a mining commodity enjoyed directly by the local community or mine producer regions. The rock is used in the construction, which includes houses, roads or buildings (Akhmaddhian \& Supriatin, 2017).

In the President Regulation Number 58 of 2017 concerning Amendment to Presidential Regulation Number 3 of 2016 concerning Acceleration of National Strategic Projects Implementation, there are some projects conducted in West Java Province namely (a) toll road infrastructure construction project; (b) inter-city railway facility infrastructure construction project consists of: South Java Double Track and Jakarta-Bandung HighSpeed Train; (c) New Airport construction project namely Kertajati Airport; (d) new seaport dan capacity development; (e) Refinery Development Master Plan (RDMP); (f) Waste-Based Energy Infrastructure Project; (g) Drinking water supply project; (h) Dam and irrigation networks consist of: Kuningan, Ciawi, Sukamahi, Leuwikeris, Cipanas, Bener, Sadawarna, and Matenggeng Dam, also construction of local irrigation network of Leuwigoong in Garut Regency. From 27 (twenty-seven) regencies/cities in West Java Province, according to data from the Energy and Mineral Resources Agency (ESDM) of West Java Province in 2018, there were only 17 regencies/cities that have mine resources with a total mining business permit (IUP) issued about 390 IUPs. Out of 390 IUPs, there were about 342 IUPs of rock or around $87 \%$ of rock mining existed in West Java Province, one of the regencies that have rock mining is Subang Regency (ESDM Agency of West Java Province, 2018).

Subang Regency has a fairly strategic location in West Java Province for the development of a national infrastructure project. Subang Regency is crossed by the Pantura route which is one of the busiest routes in Java island. Sub-districts in this route included Ciasem and Pamanukan. In addition to the Pantura route, Subang Regency is also crossed by the Sadang Cikamurang alternative roads, crossing in the middle of the Subang Regency area and connects Sadang in Purwakarta Regency with Tomo in Sumedang Regency. Subang Regency which is directly adjacent to the southern part of Bandung Regency has direct access which at the same time connects the Pantura route with Bandung City (BPS Subang Regency, 2018).

The strategic location of the Subang Regency 
for the development of national strategic projects will increase rock mining activities in the area. As published in the online news at Buana Indonesia.co.id, it was stated that there were allegedly 8 illegal $\mathrm{C}$ minerals that contributed to environmental damage in Subang Regency. Some of the mines were closed in 2014, however, later the mines, which was considered illegal, continued their operations. Some of the environmental destructions were done by mining or $\mathrm{C}$ minerals in Subang Regency included laterite mining in Rancabango village, Cikaum, Kalijati, Ranggawulung forest area, Cicadas Binong, West Pagaden, and sand mining in Cipeundeuy also rock mining in Cimanglid Kasomalang village (Ripai, 2018).

Based on the background, the formulation of the problem as follows:

a. How is the process of rock mining permit in West Java Province after the enactment of Law Number 23 of 2014?

b. How is the impact of the abolition of the authority of regency/city government for rock mining activity after the entry into force of Law Number 23 of 2014 in the Subang Regency of West Java Province?

The purpose of this study is to analyze and study the process of rock mining permit including the effectiveness and benefit from policy implementation related to the abolition of the authority of regency/city government in the rock mining activity after the enactment of Law Number 23 of 2014 in Subang Regency of West Java Province. This study is important with its unique advantages than others since this study focuses on discussing the implementation of rock mining policy with direct effects on the interest and welfare of the mining area communities. Furthermore, the research data are relatively new which focuses on rock mining permits after the enactment of Law Number 23 of 2014.
The author will use some theories related to decentralization, local autonomy and public policy implementation of MS. Grindle to analyze government policies related to the abolition of the regency/city government's authority in the field of mine and the resulted effect.

\section{Decentralization and Local Autonomy}

Decentralization is a system consisting of the delegation of powers, authority, and functions from central to the local government, which has been recognized globally as a facility to increase the delivery of goods and public services. World Bank research shows that from 75 developing countries and transition countries with populations of more than 5 million, 63 countries have started the reformation aims to transfer political strength to the local government units. The main objective of the reform is to increase equity, improve efficiency and ensure more participation and responsiveness of government to the citizens (Frumence, Nyamhanga, Mwangu, \& Hurtig, 2013).

Cheema views that the changes in government centralization to decentralization as a solution in the improvement of the quality and quantity of government services to the community. Decentralized government is also considered as the service that can bring effectiveness and efficiency due to expectations that decentralization will reduce the load and congestion in the communication and administration line, therefore the delay of government programs will reduce (Cheema, 2007).

The implementation of the government system in Indonesia is marked by changes in the government system from centralistic to decentralized. The changes in line with the changes in the law on local government which based on article 18 paragraph (2) of the 1945 Constitution and last amended by 
Law Number 23 of 2014 on Local Government by vesting broadest autonomy to the locals to accelerate the realization of community welfare (Adhayanto \& Adiputra, 2017).

The authority from central delegated to the locals has made the locals overly free to exploit natural resources without considering the impact on the environment. The number of mining business permit letters issued by the local government has become uncontrolled since the local government was given the authority by the central government. Many mining business permits issued sometimes overlapped with the mining area owned by other managers (Risal, 2017).

Furthermore, Prasojo (2006) suggested that basically decentralization is classified into four types namely deconcentration, devolution, delegation and support assignment. This support assignment is also applied in Indonesia where the macro policy is in the hands of the central government, and the source of financing is also from the central government. Meanwhile, micro policy and implementation are implemented by the local government. Accordingly, the consideration of the decentralization model must take into the effectiveness, function, and usefulness (Akbal, 2016).

Local autonomy in the NKRI Framework is basically a consequence of the existence of the decentralization system in the government. Decentralization in the government system in Indonesia based on the existence of the process of the formation of a region called local autonomy which is a place or scope where the authority is delegated from the central will be regulated, managed and implemented (Akbal, 2016).

According to Fesler and Leemans (Kaloh, 2007), local autonomy must be defined as autonomy for the community at the local le- vel and not "local" autonomy in the sense of a particular area at the local level. Therefore, local autonomy is not the objective but the instrument to achieve the goal.

The existence of advances in science and technology, the community demands the changes in general quality services that are faster and more precise. In terms of the development of technology, Iglesias stated that one of the factors that needed to be considered to implement local autonomy is technology, besides human resources and organizational structures related to the roles and organizational relations related to the program (Kaho, 2007).

Government affairs that fully become the governmental authority are those in foreign policy, defense, security, national monetary and fiscal, justice and religions. Government affairs that can be managed jointly between levels and arrangements of government or concurrent are government affairs other than government affairs which are fully the affairs of the Government. Therefore, in each field of government affairs that are concurrent, there is always part of the affairs that become the governmental authority, the provincial government, and the regency/city government (Muluk, 2006).

\section{Implementation of Public Policy}

In the implementation process of local autonomy policy, the central government seems to want to release its responsibility for local, but in a different situation, the central government also does not want to miss the source of income from the autonomous region. Even though the local government also does not want to lose their regional own source revenues because they must be accumulated in the State Budget. This makes the central government share authority with local government to ensure interest synergies between them, especially in the process of 
natural resources management at the local level (Risal, 2017).

Mining policy is a form of public policy that refers to public issues in mining management. Mining policy is not only related to the substance of mineral and coal mining law but also including local government law. In the context of public policy implementation, Ripley and Franklin stated that the implementation of the policy refers to the series of activities or actions that accompany the statements on objectives and outcomes of the program to be achieved by government officials. The intended series of activities or actions take place when a rule has been established to implement the program (Ripley \& Franklin, 1986).

The success of policy implementation according to Grindle (1980) is influenced by two major variables, which are the content of policy and context of implementation. Therefore, the government in policymaking is supposed to review whether the policy can harm the community or not. This has the purpose to prevent conflict detriment to the community (Mandala et al., 2016).

In terms of the content of the policy, Grindle (1980, p. 8) described:

Theodore Lowi has suggested that policy types will pose major impacts on types of political activities stimulated by policymaking processes. This observation can be applied with the same validity as the implementation process and encouraging the consideration of the "capacity" of various programs. The difference may also be created between programs that provide collective benefits, encourage categorization requests, and provide shared benefits, which can mobilize more types of particularistic demands at the implementation stage.

In term of this difference, Grindle (1980, p.
9) suggested:

The difference in the behavior level has changed the program to beneficiaries and it is another means of content from the policy that affects the implementation. The introduction of technology to the development of agriculture is an example generally cited from programs that require adequate behavioral adaptation and participation from the beneficiary. On the contrary, providing housing for low-income groups may require a slight pattern of behavioral changes. Besides, programs designed to achieve the long term objectives may be more difficult to apply to those who are more concerned with immediate benefits. In this context, the content of policy becomes important to analyze the direction of the policy implementation.

In this perspective, Grindle said the content of various policies also dictates the site of implementation. Further Grindle (1980, p. 10) said:

The decision made during policy formulation may also show who will be charged to implement various programs, and those decisions can affect how the policy is achieved. There may be, for instance, the difference in terms of institutional bureaucratic capacity to manage the various success of programs. Some receive greater support from political elites and have access to resources, and some will be able more to overcome the various demands made on them.

In addition, the form of policy objective might have an impact that is decisive to the implementation. Therefore, the context of policy becomes a concern. In this case, Grindle (1980, p. 12) suggested:

The content of policy and program is an important factor in determining the outcome of the implementation initia- 
tive. However, like many examples, and as can be seen in the content figure, policy or program is often an important factor because the real potential or impact may be on the given social, political, and economic arrangements. Therefore, it is necessary to consider the context or environment where administrative actions are achieved. We have prepared the implementation to be a process of decision making that will involve various actors. In the administration process for each given program, many actors are called to make choices about specific public resource allocation and many other things may be tried to affect the decision. A brief list of people who might be involved in implementing a program will include national-level planners, national, regional, and local politicians, economic elite groups, mainly at the local level, recipient groups, and bureaucratic implementers at the middle and lower level. These actors are more or less involved in the implementation, depending on the content of the program and the form provided. Each may have a special interest in this program, and each may try to achieve it by making demands on the allocation procedure. Often, the objectives of the actor will be in the direct conflict with one another and the outcome of this conflict its consequences, who get what will be determined by the strategy, resources, and authority positions of each actor involved. What is implemented may be an outcome from the calculation of political interest and groups competing for scarce resources, the response from implementer officials, and political elites, all of them are interacting in the given institutional context. Analysis of the special program implementation can be interpreted to assess the "power capacity" of actors, their interest and strategy to achieve it, and the character- istics of the regime in which they interact. This, in turn, can facilitate the assessment of the potential to achieve the policy and program objectives.

How the objective is achieved, according to Grindle (1980, p. 13):

In achieving the objective, the officials face two problems that highlight the environment and administration program interaction. First, the officials must address the problem of how to achieve policy compliance. They must, for instance, obtain support from political elites, and compliance of the executive agencies, bureaucratic burdens by implementing the programs from lower -level political elites, and beneficiaries. They must change opposition from those who might be harmed by the program to their acceptance, and they must guard those who are excluded but wishing to benefit, from destroying them. Such an appearance can imply compliance of the bargain, accommodation, and again, major conflict.

However, if the overall policy objective is to be realized, resources are transacted to obtain compliance that must not harm the impact of program specificity. For this purpose, understanding the dimension of other policy problems is needed, according to Grindle (1980, p. 13):

The other side of the policy problem and achieving the program objectives in a particular environment is responsiveness. Ideally, public institutions such as bureaucracy must be responsive to the most adequate needs for them to serve them. In addition, without sufficient responsiveness during implementation, public officials who lose information to evaluate the programs achievement and support can imply that the policy objectives are not achieved because of interventions from the same individuals or 
groups both in the framework of obtaining specific types goods and services in the greater number or to prevent the fulfillment of particular programs that cannot be accepted profitable by them. The problem for policy administrators is to ensure a sufficient number of responses to provide flexibility, support, and feedback, while at the same time maintaining sufficient control over the resources distribution to achieve the intended objective. This is the balance to achieve, and which requires considerable political intelligence in taking into account the possible responses of actors involved and their capacity to subvert the program objective. To be effective, then, implementers must be skilled in the art of politics and must understand well the environment in which they strive to realize the public policies and programs.

Therefore, commitment is required from the stakeholders. Grindle (1980, p. 14) said:

The theme raised in several case studies is the extent to which political regimes and administrative organizations are committed and have the strength to implement their policies. In this problem, decentralization occurs or on the other side, controlled from the central politics or state bureaucracy. Our study suggested that the political system that does not concentrate on broad central powers does not necessarily decentralize the authority of implementation or responsibility if they want to see their objectives achieved. They may fail because they have little control over the sanctions needed to obtain compliance with program objectives. Decentralization can be a feasible strategy in which the central government maintains the capacity to ensure that implementation activities remain within the limits of the structure and objectives of the program.
In the context, the considerations according to Grindle (1980, p. 14) are:

This suggestion shows that the consideration of administrative action context also involves variables such as the structure of political institutions and types of regimes where policy or programs are achieved. Ideology, culture, political alliances, and rewards, also other international events and environmental effects may also have a significant impact on the administration process. Moreover, the programs are not implemented separately from other public policies, the success of a program can easily be influenced by the priority of political officials or results from other programs. These factors imply that identical programs in the content can still be implemented, and it is different if the achieved context is different substantially.

How factors suggested by Grindle correlate one with another is shown in Figure 1.

\section{Rock Mining Management}

Article 2 of Government Regulation Number 23 of 2010 classified mineral and coal mining into five groups namely, radioactive minerals, metal minerals; nonmetallic minerals, rock and coal. The examples of rock mining are mountain rocks, filling sand, tidal sand, sandstone, filling soil, etc.

Rock mining emerged after the issuance of Law Number 4 of 2009, as mentioned by Sitinjak as staff of the Directorate General of Mineral and Coal of the Ministry of Energy and Mineral Resources that the terminology of class $\mathrm{C}$ minerals previously regulated in Law Number 11 of 1967 has been amended by Law Number 4 of 2009, into rock mining. Therefore, the use of term class $\mathrm{C}$ minerals is no longer appropriate and replaced with rock and the granting of rock IUP is based on Government Regulation Number 23 of 


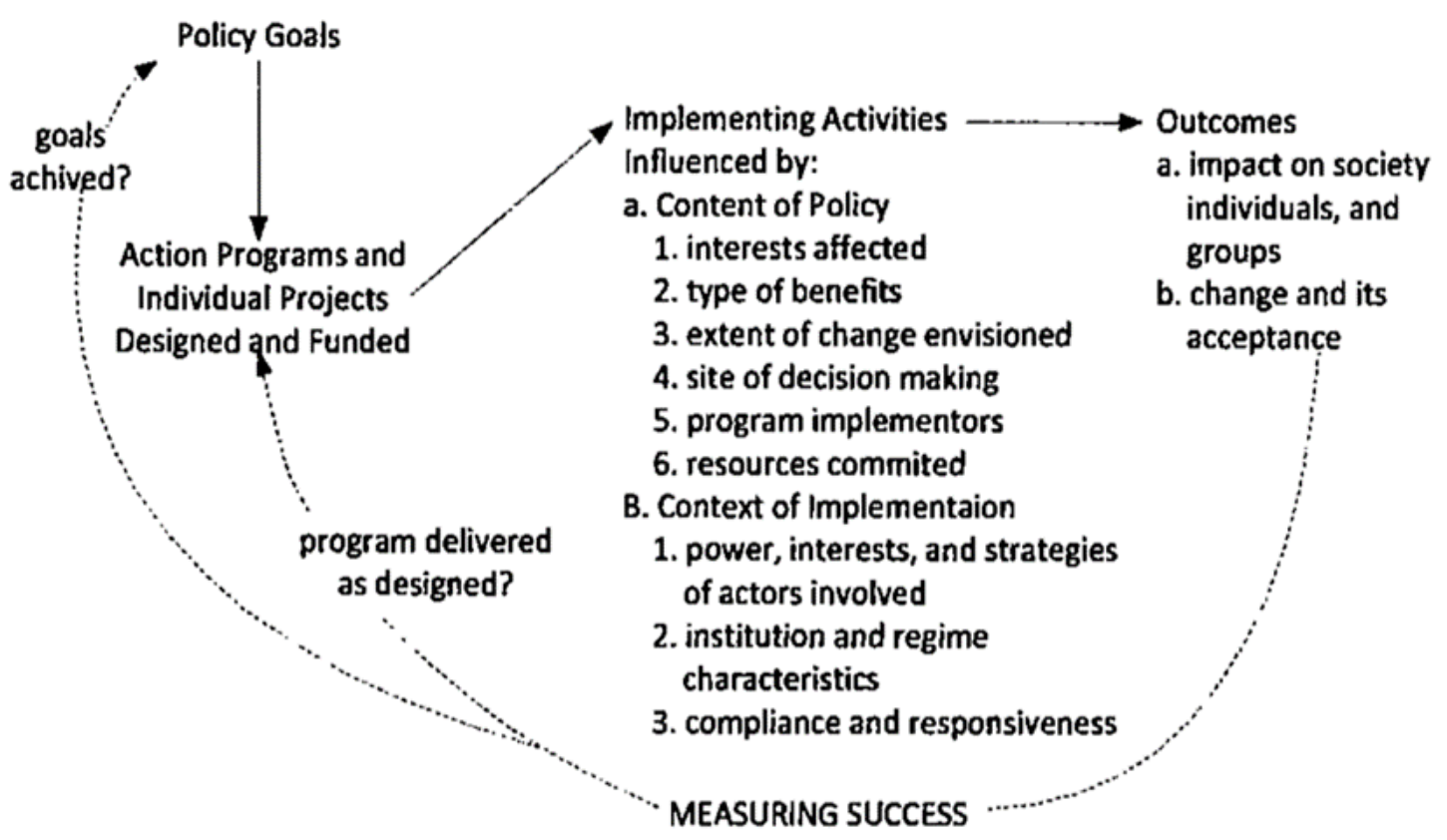

Figure 1. Correlation of the factors

Source: Grindle (1980:11)

2010 done through the regional application. The requirements to be fulfilled by the applicant for an IUP are administrative, technical, environmental, and financial (Sitinjak, 2019).

Prior to the issuance of Law Number 23 of 2014, West Java Provincial Government issues Local Regulation Number 17 of 2001 as revised into Local Regulation Number 2 of 2012. Next, Subang Regency issues Local Regulation Number 6 of 2006 on mining management including Local Regulation Number 7 of 2001 and last revised to Local Regulation Number 1 of 2014 on non-metal mineral and rock mining business. Following the issuance of Law 23 of 2014, West Java Province issued Local Regulation Number 2 of 2017 on Mining and Mineral Management including Local Regulation Number 3 of 2017 on One-stop Integrated Permit Service (PTSP).

Permits activities are the initial steps for investors or communities who will carry out mining activities in Indonesia. Permits are issued according to the location and exis- tence of mine including the authority of each region (Mantoro, 2012). Sitinjak also said that the rock mining business activity itself is different from other mining, both from how to obtain, time permits, area of business permit, or revenue received by the state from the mining activities results. Related to state revenue, rock mining activities are not subject to royalty or production fees, but the results of the production of rock mining go directly to the revenue of regency/city government where mining activities are carried out. Therefore, rock mining tax production is not included in the classification of state revenue which must be divided between central and local government or often referred to as the balance fund. Non-metal mineral and rock tax is a type of regency/city tax according to Law Republic of Indonesia Number 28 of 2009 on Local Tax and Local Retribution (Rumengan, Karamoy \& Pusung, 2015).

Widayati, Usman and Sriyanti (2014) said that mining activities without a permit will affect the local and environment tax retribution where mining activities are carried out. Meanwhile, the environmental damage is 
caused by illegal mining businesses cannot be supervised directly by the government as the mining permit provider and those illegal business actors do not pay reclamation bonds for post-mining activities. Environmental management must lead to the guarantee of environmental sustainability according to Law Number 32 of 2009 on Environmental Management. Environment defined as a unity of space of all objects, power, conditions, and living creatures, including humans and behaviors, which affects the nature itself, survival of life, and humans welfare including other living creatures. Not a few company mines that have pocketed a permit also often not paying the reclamation guarantee fund regulated by the local government. Unfortunately, the local government does not take decisive action to punish such mining companies (Hilmawan, Yudaruddi \& Wahyuni, 2016).

Local autonomy policy on in the environment has an impact on the creation of the concept of solving environmental problems which emphasizes the dimension of local wisdom of each local community rather than the solving of environmental problems based on high technology. With the existence of local autonomy, it is a capital for Indonesia to implement the decentralization of environmental governance as an alternative effort to solve environmental problems (Mina, 2016).

Legislations that give authority to the local in carrying out the management of natural resources, should be done the synchronization of the content material between the law of local government with natural law and environmental resource management, with the hope that the two laws will not cause problems in the implementation, mainly relating to attraction interest between central and local. So that it can prevent and avoid prolonged conflict of interest between central and local (Suhartono, 2013).

\section{The Perspective of the Researcher}

The broadest local autonomy given by the central government to the regency/city government gives the impression of the existence of small kings at the local so that natural resource management seems to belong to the regency/city government that can be managed directly.

The existence of direct management by regency/city government raises many problems at the local level and central government faces difficulty to control the problems, such as a large number of mining areas that are overlapped as the result of regency/city government is too easy in issuing the permits also the environmental impact due to its less optimal natural resources management.

Rock mining activities are different from other mine types, such as metal mine and coal because the results of rock mining are felt directly by the community and regency/ city government, where the results of rock mining activities can be used to carry out development at the local level. The sales tax of rock mining goes into the government regulation/city in which rock mining activities are carried out. So that there is no need the profit sharing between central, provincial and regency/city government also former mines can be utilized directly as agricultural or plantation land. With a shift of authority from regency to the province will complicate and prolong the process of issuance of rock mining permits, meanwhile the needs of rock mining by the community cannot be postponed for development activities.

\section{RESEARCH METHOD}

\section{Research Design}

The research design is descriptive analysis with a qualitative approach. Locke, Spriduso, and Silverman (in Creswell, 1994) suggested 
that qualitative research is interpretative research. As such, the biases, values, and judgment of the research have been stated explicitly in the research report. Such openness is considered to be useful and positive. The overall research data results obtained directly in research field through observation and interview with key informants and secondary data captured by a qualitative approach and carefully processed by avoiding errors in the recording on overall of development also data rolling that is always changing in each situation as well as empirical conditions related to the authority of rock mining activities after the enactment of Law Number 23 of 2014 on Local Government.

\section{Data Collection Method}

Based on the research method and approach used, the data collection process carried out in a natural setting refers to participatory observation, in-depth interviews, and documentation. This refers to the Marshall and Rossman's statement that the fundamental methods relied on by qualitative researchers for gathering information are, participation in the setting, direct observation, in-depth interviewing, and document review (Sugiyono, 2005).

Research informants can be divided into three categories, namely mine entrepreneurs, communities and policy implementers consisting of Investment and One-Stop Integrated Permits Agency (DPMPTSP) of West Java Province, Energy and Mineral Resources Agency of West Java Province, Environmental Agency (LH) of Subang Regency, Local Revenue Agency of Subang Regency and heads of villages around the mine.

\section{Data Analysis}

Examination of data in qualitative research is necessary to collect data, trusted and show data legality as the most strategic step in re- search because the main objectives of the legality examination are to get data that meets the established standards. Therefore, the research uses data source representation patterns and data classification. Data legality, classification, and analysis are done by the triangulation approach.

The research location was Subang Regency as the area where rock mining activities exist and as the area that receives the benefits also the effects of mining policy changes under Law Number 23 of 2014. The research was conducted in July 2019.

\section{RESULT AND DISCUSSION}

Primary data in the form of interviews and secondary data in the form of the literature review are processed in triangulation and analyzed using the implementation policy model according to Grindle (1980) with two major variables which are content of policy and context of implementation which later is broken down into 9 sub-variables, namely:

1. Interest Affected

To analyze the elements, the researcher raised questions to the informants, what interests are affected by the existence of the policy of governmental authority abolition in providing the mining permit according to Law Number 23 of 2014 in Subang Regency area? Informant 1 and 2 (officials of ESDM Agency and DPMPTSP of West Java Province) provided answers:

The affected interest is the regency government's interest because by the enactment of Law Number 23 of 2014 the regency government authority in issuing mining permits is lost. From the applicant, initially he/she feels shocked because there are many changes in habits. Previously in applying for an application in regency, he/she find it easier and faster because there are stages that can be bypassed such as in the stage of activity 
exploration can be skipped by only making exploration reports. With the shift of authority to the province, the stages are enforced so strictly that they feel the issuance of permits in the province is longer and more difficult.

Informant 6 (mine entrepreneurs) has confirmed the questions as follows:

If the regency that issues permits is faster, as long as the money is available, it must be worked out, for example there is 100 million rupiah, 200 million rupiah, it must be issued, but if the process is longer and more time spent in the province and the money is also more, then there is no use of it.

In this matter, Grindle (1980, p. 9) suggested that "the difference in the behavior level changes the program to beneficiaries is another way of policy content affects the implementation".

Subsequently, Frumence, et al. (2013) said that decentralization is a system consisting of the delegation of powers, authority, and functions from central to the local government, which has been recognized globally as a facility to improve the delivery of goods and public services. The main objective of the reform is to increase equity, improve efficiency and ensure more participation also the responsiveness of government to the citizens.

Based on the interview results, secondary data and theory, the researcher suggested that the most interest party is the mine worker community (mine entrepreneur), Subang Regency's Local Revenue Agency including ESDM Agency of West Java Province as the technical agency in the issuance process of a rock mining permit.

\section{Type of Benefits}

The researcher raised questions to the in- formants, what kind of benefits are expected by the West Java Provincial government from the authority abolition of the regency government in issuing the rock mining permit according to Law Number 23 of 2014? Informant 1 and 2 (officials of ESDM Agency and DPMPTSP of West Java Province) provided the answers:

One of the expectations is well-managed mine, making none of the government levels that have absolute authority. Therefore, between levels of government have mutual control and conflict of interest does not occur. This should be a joint responsibility and between levels of government must be more harmonious.

Informant 6 (mine entrepreneurs) provided the answer:

Albeit mining activities carried out without permission. There is no conflict between the excessive community. Usually in the dry season is a lot of dust, and people are impatient also request water sparkling rashly. The conditions will make up to 3 to 4 times day water sparkling to the road. In general, the community supports the mining activities because prior to sand mining, most farmers run brick printing companies. Until now, there are around 25 brick printing companies, and even motorcycle taxi drivers are imposing themselves to buy cars or transporting sand.

Informant 5 (village heads) provided the answer:

So far, there have been no serious complaints because all have been handled by the company, for example, related to road damage has been repaired and even re-casted by the company. Related to dust caused by material carrier vehicles, the company did water sprinkling three times a day and gave money to the residents whose houses located in the roadside which is passed by sand transporter 
vehicles.

Informant 7 (mine workers) said:

There is no complaint because there are many company's services to the community, such as if there are public works, if there is a need, they also come here to give. For instance, if sand is needed, they will give it. Also, usually some citizens asked for money on the road, also there is money given by the company illegally, to the houses in all left and right of the roadside.

In this matter, Grindle (1980, p. 9) said that: The difference in behavior level changes the program to beneficiaries is another way of policy content affects the implementation. Besides, programs designed to achieve long-term objectives may be more difficult to apply to those who are more concerned with immediate benefits. In this context, the content of policy becomes important to analyze the direction the policy implementation.

Furthermore, Prasojo (2006) suggested that basically decentralization is classified into four types namely deconcentration, devolution, delegation and support assignment. The support assignment is also applied in Indonesia where macro policy is in the hands of the central government, the source of financing is also from central, meanwhile, the micro policy and its implementation are implemented by the local government. Therefore, the determination of the decentralization model must take into account the effectivity, function, and usefulness (Akbal, 2016).

From the informants' answers and related to opinions suggested by Grindle and Prasojo, the researcher argues that the types and benefits expected from the provincial government are not too affected on rock mining activities at Subang Regency. This is because the community only hopes how mine entrepreneurs pay attention to the surrounding environment and can help community welfare around the mine. If these expectations have been fulfilled by rock mining entrepreneurs, then there will be no conflict caused by rock mining activities between mine entrepreneurs and the communities around the mine.

\section{Extent of Change Envisioned}

The researcher raised a question, what are the desired changes through government authority abolition in issuing rock mining permits in accordance with Law Number 23 of 2014? Informant 1 and 2 (officials of ESDM Agency and DPMPTSP of West Java Province) provided the answer: "The changes in the mining area map from the manual to the digital system and the increasing of local revenue both in terms of land use as well as retribution of mining activities production results”.

Informant 6 (mine entrepreneurs) provided the answer:

At the time of field scheduling, the consultant said that previously we must prepare money then they come to the field. For the Mining Business Permit Area (WIUP), I must prepare 20 million $\mathrm{Ru}-$ piah that accidentally I give it by myself at the field and then I print the WIUP by myself with the cost incurred 750,000.00 Rupiah.

Informant 4 (Official of Local Revenue Agency of Subang Regency) provided the answer: Regarding the mine management, it is the authority of the provincial-level but the tax of Non-Metal Mineral and Rock (MBLB) is still being accepted by regency. However, related to the issue of collecting the mining tax, we only can collect from the mines that hold permits. The problem that occurred recently is many mining activities do not have per- 
mits. We have sent a letter to the ESDM Agency at the province-level related to the existing mining activities problem in Subang Regency.

In this matter, Grindle (1980, p. 8) suggested:

The type of policy made will have a major impact on the types of political activities stimulated by the policymaking process. This observation can be applied with the same validity with the implementation process, encouraging consideration of the "capacity" of various programs. The difference may also be made between programs that provide collective benefits, which encourage categorization requests, and they provide shared benefits, which can mobilize more types of particularistic demands at the stage of implementation.

From the answers of the informants and Grindle's view, the researcher suggested that expected changes with the shift of authority have not been reached optimally, because the implementor still expects the existence of compensation in providing services to the community as the applicant of mine permit.

\section{Site of Decision Making}

The researcher raised a question, who is authorized to make strategic decisions in determining the policy for granting rock mining permits after the Law Number 23 of 2014 in West Java Province? Informant 1 and 2 (officials of ESDM Agency and DPMPTSP of West Java Province) provided the answer: "the authority to make strategic decisions is the Governor or the Regional Secretary through a proposal from the Head of Agency at the provincial level meanwhile the Regent at the level of Regency".

Next, the researcher asked additional questions who is the leading sector in issuing the mining permits? Informant 2 (DPMPTSP) provided the answer:
Until now, the leading sector institution in granting mining permits in Subang Regency and West Java Province was the ESDM Agency of West Java Province and it is supposed to be DPMPTSP as the leading sector so that we still rely on the technical agency from ESDM.

In article 19 of West Java Province, Local Regulation No. 2 of 2017 on mineral and coal mining management states the issuance of IUP is carried out by local apparatus in charge of permits affairs. Next, in the West Java Governor Regulation Number 62 of 2016 on main tasks, functions, unit task details and work procedures of DPMPTSP article 17 (1) states that the forestry, environment, energy and mineral resources section has the main tasks of carrying out forestry sector permits, environment, energy and natural resources, including permit registration process, technical consideration process, and permits issuance process. On this matter, the researcher suggested that there is still an overlap of authority at the provincial level. It is needed for the existence of willingness or policy from the Governor/Regional Secretariat to combine the technical agency related to permits in one agency with DPMPTSP so that DPMPTSP can become the leading sector in providing the mining permit.

\section{Program Implementer}

The researcher raised a question, how was the law implemented and who carried out the law? The answer provided by informant 1 and 2 (officials of ESDM Agency and DPMPTSP of West Java Province) are:

The implementer of the law or regulation is DPMPTSP of West Java Province as the place for registering and issuing the permit. The registration is online, ESDM Agency of West Java Province conducts technical discussions and the results of technical studies are submitted to the DPMPTSP. 
Informant 2 (DPMPTSP) continued the answers:

Regarding the permits, technical agencies are still not optimal because the tasks of technical agencies are more numerous in supervision mining management. Thus in terms of permits cannot be implemented optimally and the most frequent constraints are related to human resources, where the technical team is not attached to us so that when we are scheduling to do a site check we often find it difficult to match the schedule because the technical team is still ad hoc. When we propose to check the field related to permits, they have other tasks from their leaders. Usually, they always argue with that reason so that they request to postpone the schedule until we find the appropriate schedule.

In this perspective, Grindle (1980, p. 10) said:

The decision made during policy formulation may also indicate who will be charged to implement various programs, and the decision can affect how the policy is achieved. There may be, for instance, a difference in the terms of the institutional capacity of the bureaucracy to manage various successful programs. Some receive greater support from political elites and have access to resources, and some will be more able to overcome the numerous demands made on them.

Based on the information and opinion suggested by Grindle, the researcher suggested that the implementer of the rock mining permit issuance program should be DPMPTSP assisted by the technical team from the ESDM Agency of West Java Province. However, the program implementer is still not optimal in carrying out its activities according to their duties so that it inhibits in providing the permits in the Subang Regency area.

\section{Resources Committed}

The researcher raised questions, what resources are required to support the effectiveness of the issuing of rock mining permits after Law Number 23 of 2014 in the Subang Regency area and how are these resources available in the provincial government as the policy implementer? Informant 2 (DPMPTSP) provided the answer:

Resources needed are human resources, related to the number of personnel and personnel technical skill. The budget relates to increasing benefits on human resources that carry out the task in the field of mining and permits. Integrated technology from PTSP Agency and related technical agencies, so that all can be done online. From these resources, it is explained that the performance of resources is not optimal, because there are still many employees who do not have technical qualifications and employees from Regency Government who still have the old mindset and empowered in their old locations, so that there are still causing the opportunity to deception outside standard operating procedures. Meanwhile, budget resources are not operational constraints because of what we need, the local government always responds. Regarding integrated technology, there are still found constraints according to the answers given. In the process of permit issuance, due to the change of status of the PTSP Coordination Board into PTSP Investment Agency, DPMPTSP must have become the leading sector in providing the permit but the leading sector is still in the ESDM Agency.

Informant 1 (officials of ESDM Agency of West Java Province) added "the human resources must be fulfilled either in terms of number as well as quality. Up to now in 
ESDM Agency, there was a lack of personnel in the field of mining".

In this matter, Grindle (1980) said:

Decision made during policy formulation may also show who will be charged by implementing various programs, and the decision can affect how the policy is achieved. There may be, for instance, the difference in the terms of the institutional capacity of the bureaucracy to manage various successful programs. Some receive greater support from political elites and have access to resources, and some will be more able to overcome the various demands made on them.

Based on the answers of the informants and opinions by Grindle, the researcher concluded that the government has not provided optimal human resources. Consequently, this lack of human resources is one of the constraints in providing the services to the public related to mining permits.

\section{Power, Interests, and Strategies of Actors Involved}

The researcher raised a question, who are involved in issuing the mining permit after the enactment of Law Number 23 of 2014 on Local Government? Informant 1 and 2 provided the answer:

Those involved in issuing the mining permit after the enactment of Law Number 23 of 2014 on Local Government among others from Province are PTSP Investment Agency as issuer permit, ESDM Agency as a technical party and Environmental Agency and Local Revenue Agency of Subang Regency.

It is continued with the question, what interests are affected by regional government authority abolition policy in issuing the mining permit following Law Number 23 of 2014 in the Subang Regency area? Informant 1 and 2 (officials of ESDM and DPMPTSP
Agency of West Java Province) provided the following answer:

The affected interest is regency government because with the enactment of Law 23 there is an abolition of authority in Subang Regency related to mining permits. The applicant initially feels shocked because there are many changes inhabits. Previously, applying regency to find it easier and faster because there are stages that can be bypassed such as in the stage of activity exploration can be skipped by only making exploration reports. But, with the shift of authority to the province, the stages are enforced so strictly that they feel that the issuance of permits in the province is longer and more difficult.

Later continued with the question, are there any problems that arise from the affected interests, and how to overcome the problems? Informant 1 (officials of ESDM Agency of West Java Province) provided the answer:

There is still a connotation of this permits that it is money-making area so almost all regencies in Indonesia are not willing to switch to the province. There are many livelihoods lost but regionally, systematic and comprehensive arrangements should be better. The purpose of the "money-making part" is that there is an interest in government regency perpetrators for personal economic interest. It could be the head of regency or perpetrators in the regency.

Then, it is continued with the question, how does the West Java Provincial Government overcome the problems? Informant 1 and 2 (officials of ESDM Agency and DPMPTSP of West Java Province) provided the following answer:

By creating an online system in the issuance of mining permits where the contact between the applicant and the permits 
manager becomes less. The only problem is the permits processes such as mining and the environment, The term of subjective documents which is the validity of the document needs to be tested. Therefore, it is inevitable to the existence of contact due to the discussion of the document. This is the constraint of the online system so that not all can be done online.

Informant 3 (Official of Environmental Agency of Subang Regency) provided the following answer:

One of the influences is the changes of organization form that used to be in the form of the Environmental Board (BLH), now become an agency and joined with the sanitary sector and is now issuing environmental permit through DPMPTSP Subang Regency which is previously published directly by BLH Subang Regency. Meanwhile, if it is related to performance in the mining permit framework is still the same and we are even more glad that the authority has been moved to the province because providing recommendations have a long time to check the situation in the field.

Informant 4 (Official of Local Revenue Agency of Subang Regency) provided the answer:

If it is possible, we can collect taxes not related to permits such as land and building tax. In essence, they have objects that we can withhold its land and building tax. Similar to the mining activities, if they do activities, we can collect the tax. Meanwhile, informant 7 (mine workers) provided the answer: usually the deception happens when handling the environmental permit and technical discussion in the branch agency. That is what I experienced. But if in PTSP Investment Agency, I think there is no deception, because they only accept readymade goods from the technical agency.
Informant 6 (mine entrepreneurs) provided the answer:

If for example, the process is not longwinded, the faster it will be and the tax will be received faster. If this is happened, how to pay the tax? It will not be accepted. In the end, we coordinate with the local personnel and the mine area environment.

Grindle (1980, p. 12) said:

We have prepared the implementation to be a process of decision making that will involve various actors. In the administration process, each given program, many actors are called to make specific public resource allocation choices and many other things may be tried to affect the decision. A brief list of people who might be involved in implementing a program will include national-level planners, national, regional, and local politicians, economic elite groups, mainly at the local level, recipient groups, and bureaucratic implementers at the middle and lower level. These actors are more or less involved in the implementation, depending on the content of the program and the form provided. Each may have a special interest in this program, and each may try to achieve it by making demands on the allocation procedure.

Based on the information of the informants and opinions suggested by Grindle, the researcher suggested his opinion that there is still a conflict of interest between DPMPTSP as an issuer permit with the ESDM Agency as a technical function that provides technical recommendations on mining permits. For this interest, DPMPTSP hopes that the issuance of permit one roof is carried out by combining the technical office in one building with DPMPTSP so that there is a synergy in providing the mining permit service in the region. 


\section{Institution and Regime}

The researcher raised a question, how is the support from related agencies in the implementation of the policy for issuing rock mining permits after Law Number 23 of 2014 in the Subang Regency area? Informant 2 (DPMPTSP) provided the following answer:

Until recently the institution which was the leading sector granting mining permits in Subang Regency and West Java Province was ESDM Agency of West Java Province and it was supposed to be DPMPTSP as the leading sector. Thus, we still depend on the technical agency from ESDM and related to permits issues, technical agencies are still not optimal because the tasks of technical agencies are more numerous in the field of supervision of mining management, so that in the case of permits it cannot be carried out optimally.

Informant 6 (mine entrepreneurs) provided the following answer:

Usually, the deception is when handling the environmental permit and technical discussion in the branch agency. That is on my perception. But if in the PTSP Investment agency, I think there is no deception because they only accept finished goods from the technical agency.

In this matter, Grindle (1980, p. 12) said: What is implemented may be an outcome from the calculation of political interest and groups competing for scarce resources, the response from the implementer officials, and political elites. All interaction is in the given institutional context. Analysis of the special program implementation can be interpreted to assess the "power capacity" of actors. Their interest and strategy to achieve it, and the characteristics of the regime in which they interact. This would, in turn, facilitate the assessment of the potential to achieve the policy and objectives of the program.

Based on the answers of the informants, the researcher suggested that the characteristics of institutions and regimes relating to the issuance of rock mining permits with the displacement of this authority have not changed so that there are still characteristics wishing to be served and expecting compensation from the community in providing the permit services.

\section{Consistency and Responsiveness}

The researcher raised a question, is there a good refusal from the community or the Subang Regency Government related to the authority abolition of the Subang Regency Government related to the issuance of rock mining permit after the Law Number 23 of 2014 in Subang Regency area? Informant 1 and 2 (officials of ESDM Agency and DPMPTSP of West Java Province) provided the answer:

In the beginning, many refusals occurred either by regency/city government also company and community that applied for permit application. The initial problem from regency/city is because they feel that their authority is eliminated meanwhile from the applicant because the permits process were getting longer and more time including the policies being carried out increasingly strict.

Informant 5 (village heads whose area covered rock mining activities) said:

We expect the permits process to be speeded up and the process should not be too complicated because once again from the community there are no problems related to mining activities and here there are needs of community also needs of villages government related to development issues.

Informant 6 (mine entrepreneurs) provided the following statement: 
If the regency that issues permits is faster, as long as the money is available, it must be worked out, for example there is 100 million rupiah, 200 million rupiah, it must be issued, but if the process is longer and more time spent in the province and the money is also more, then it is just a lie.

Grindle (1980, p. 13) said that:

The other side of the policy problem and achieving the objectives of the program in a particular environment is responsiveness. Ideally, public institutions such as bureaucratic must be responsive to the needs of the most adequate for them to serve them. Besides, without sufficient responsiveness during implementation, public officials who lose information to evaluate the achievements of the program to be effective, then, implementers must be skilled in the political arts and must understand well the environment in which they strive to realize public policy and the programs. Related to compliance, Grindle stated in achieving the objective. The officials faced two problems that highlighted the environment interaction of the program and program administration. First, the official must address the problem of how to achieve policy compliance. They must, for instance, obtain support from political elites, and compliance of implementing agencies, bureaucratic loading with program implementation from lowerlevel political elites, and beneficiaries.

Data of permits obtained from DPMPTSP West Java of 2019, there were found information that during 2015 until 2018 the number of mining application from Subang Regency area were 65 applications and from those number, only 12 permits were completed. The length of the issuance of WIUP ranges from 4 months to 18 months.
Meanwhile, in the appendix of Minister of Energy and Mineral Resources Regulation Number 43 of 2015 states the issuance period of WIUP is 14 days, IUP Exploration is 14 days and mining business permit of production operations (IUP OP) is 14 days. West Java Governor Regulation Number 1 of 2018 on implementation regulation of one-stop integrated services in its appendix states that the period of issuance of WIUP is 60 days, Exploration IUP is 30 days and IUP OP is 60 days.

Based on the informants' information and opinions suggested by Grindle, the researcher concluded that the consistency and responsiveness of the provincial government on the process of issuing permits after the Law Number 23 of 2014 was not optimal so that the issuance of rock mining permits in Subang Regency the area can never be completed according to the prescribed time.

\section{CONCLUSION}

Prior to the enactment of Law Number 23 of 2014, Subang Regency Government in issuing the mining permits is based on Local Regulation Number 7 of 2001 and most recently changed to Local Regulation Number 1 of 2014 on Non-metal Mineral and Rock Mining Business. The leading sector in the issuance of a rock mining permit conducted by the Subang Regency is the ESDM Agency. The issuance process of rock mining permits conducted by the ESDM Agency of Subang Regency is relatively simple so that the time of permits issuance is not long or around the 3 months.

After the enactment of Law Number 23 of 2014, article 14 points a states that the implementation of government affairs in the field of forestry, marine, including energy and mineral resources is divided between central and provincial governments. This im- 
plies that the Subang Regency authority has been lost its mining management. Next, West Java Province issued Local Regulation Number 6 of 2016 on the formation and arrangement of regional apparatus of West Java Province and later issued West Java Governor Regulation Number 62 of 2016 on main tasks, functions, unit task details and work procedures of DPMPTSP that makes DPMPTSP as a leading sector in the issuance of permits or not permits strengthened by Local Regulation Number 2 of 2017 on mining and mineral management. With the displacement of authority, it causes longer and more time spent in the processing of rock mining permits in Subang Regency area, the causing factors are as follows:

1. Long bureaucracy, involving the Environmental Agency of Regency to environmental permit requirements, the Provincial ESDM Agency as a technical function and DPMPTSP as the party that issues the permit;

2. Increased and broader area coverage, because the province must serve all regencies/cities;

3. The types and benefits that are expected from the provincial government are not too influential on rock mining activities in Subang Regency because the community only hopes how mine entrepreneurs take into consideration the surrounding environment and can support the community welfare around the mine;

4. The corrupt culture of the implementer apparatus has not changed so that there are still needed transactions that require a large amount of cost in providing permit services mainly in the technical agency;

5. Lack of support of technical agencies to the DPMPTSP as a leading sector of permits and non-permits, so that there is often a non-synchronized schedule in technical discussion in providing the services to the community;

6. Human resources are not sufficient in terms of quantity or technical capacity, either in the technical agency and DPMPTSP of West Java Province;

7. There is still a conflict of interest between DPMPTSP as permit issuer with the ESDM Agency as a technical function that provides technical recommendations on mining permits;

8. The institution characteristics and regime related to the issuance of rock mining permits with the displacement of this authority have not changed so that there are still characteristics of wishing to be served and expecting compensation from the community in providing the permit services.

9. Consistency and responsiveness of the provincial government on the process of mining permits issuance after the Law Number 23 of 2014 is not optimal so that issuance of rock mining permits in Subang Regency area can never be completed within the specified timeframe.

The social impact of authority abolition of regency/city government related to rock mining activity after the enactment of Law Number 23 of 2014 in Subang Regency West Java Province, is not significant because the community around the area is greatly helped by the existence of mining activities. Also, the community has never seen whether those who carry out mining activities have a permit or not. In terms of environment, the impact is not significant because the mining entrepreneur prior to the activity conducts coordination with the local community and makes written agreements that are known by community leaders, village apparatus and subdistrict officials. So that, in doing mining activities the mine entrepreneurs always pay attention to the surrounding environment and former mines can be utilized by the landowner as agricultural or plantation land. However, due to the length of the permit formality process, the community who wish to work properly by taking care of the permit is disadvantaged. Consequently, many people decide to carry out mining activities without 
permits. This will cause the revenue from rock mining not optimal.

Based on the conclusion, the researcher provides suggestions for the effectiveness and optimization of rock mining permit issuance in Subang Regency as follows:

1. Utilization of Information and Communication Technologies (ICT) in the coordination between DPMPTSP as the leading sector and ESDM Agency as a relevant technical agency in the issuance of a rock mining permit;

2. Placement of technical office personnel relevant to mining permits in one office with DPMPTSP;

3. Placement of technical branch agency in each regency/city of rock mining producer;

4. Capacity building of personnel in technical mining through training;

5. Addition of technical personnel through personnel recruitment based on the required competence.

Based on the results, the researcher offers recommendations to conduct further research on the impact related to local revenue as the consequence of the shift of rock mining permit authority from Subang Regency to West Java Province after the Law Number 23 of 2014 on Local Government.

\section{REFERENCES}

Adhayanto, O., \& Adiputra, Y. S. (2017). Dampak Undang-Undang Nomor 23 tahun 2014 terhadap peraturan daerah di Kabupaten Bintan tahun 2015. Jurnal Selat, 2(2), 296-314.

Akbal, M. (2016). Harmonisasi kewenangan antara Pemerintah Pusat dan Pemerintah Daerah dalam Penyelenggaraan Otonomi Daerah. Jurnal Supermasi, XI(2), 99-107.

Akhmaddhian, S., \& Supriatin, L. (2017). Kewenangan perizinan usaha per- tambangan pasca berlakunya undang undang pemerintahan daerah (studi di Kabupaten Kuningan Provinsi Jawa Barat). Unifikasi, 4(2), 64-76.

BPS Subang Regency. (2018). Subang in numbers (Subang dalam Angka). Subang: BPS Subang Regency.

Cheema, G., \& Rondinelli, D. (2007). Decentralizing governance: Emerging concepts and practices. Wasington DC: Brooking Institute Press.

Creswell, J. W. (1994). Reaserch design, pendekatan metode kualitatif, kuantitatif dan campuran. Jakarta: Pustaka Pelajar.

ESDM Agency of West Java Province. (2018). Mining permits data of West Java Province (Data Perizinan tambang Provinsi Jawa Barat). Bandung: ESDM Agency of West Java Province.

Firmansyah, A. A., \& Evendia, M. (2015). Harmonisasi Pengaturan Kewenangan Daerah Bidang Pertambangan Mineral Bukan Logam dan Batuan. Kanun, 17(1), 19-36.

Frumence, G., Nyamhanga, T., Mwangu, M., \& Hurtig, A. K. (2013) Challenges to the implementation of health sector decentralization in Tanzania: experiences from Kongwa district council. Global Health Action, 6(1), 1-12. doi: 10.3402/ gha.v6io.20983

Government Regulation Number 23 of 2010 concerning implementation of Minerba mining activities (Peraturan Pemerintah Nomor 23 Tahun 2010 tentang pelaksanaan kegiatan pertambangan Minerba). Retrieved from http://eiti.ekon.go.id/ v2/wp-content/uploads/2017/o7/PP-23 -Tahun-2010.pdf

Grindle, M. S. (1980). Politics and policy implementation in the third world. New Jersey: Priceton University Press.

Hilmawan, R., Yudaruddi, R., \& Wahyuni, Y. S. (2016). Coal mining operations and its impact on sectoral and regional area: Evidence of East Kalimantan, Indonesia. Journal of Indonesian Applied Economics, 6(1), 22-43. doi: 10.21776/ ub.jiae.2016.006.01.2 
Isnaeni, D. (2018). Implikasi Yuridis Kewenangan Pemerintahan Daerah dalam Pemberian Ijin Pertambangan Menurut Undang undang Nomor 23 tahun 2014. Yurispruden, 1(1), 35-46. doi: 10.33474/yur.v1i1.734

Kaho, J, R. (2007). Prospek otonomi daerah di Negara Indonesia. Jakarta: PT. Raja Grafindo Persada.

Kaloh, J. (2007). Mencari bentuk otonomi daerah: Solusi kebutuhan lokal dan tantangan global. Jakarta: PT. Rineka Cipta.

Law of The Republic of Indonesia Number 4 of 2009 concerning Minerba (Undangundang Nomor 4 Tahun 2009 tentang Minerba). Retrieved from https:// eiti.ekon.go.id/v2/wp-content/ uploads/2017/07/UU-4-TAHUN2009.pdf

Law of The Republic of Indonesia Number 23 of 2014 concerning local government (Undang-undang Nomor 23 Tahun 2014 Tentang Pemerintahan Daerah). Retrieved from https:// peraturan.bpk.go.id/Home/ Details/38685/uu-no-23-tahun-2014

Local Government Regulation Number 7 of 2001 concerning mining exploitation (Peraturan Daerah Nomor 7 Tahun 2001 tentang pengusahaan pertambangan). Retrieved from http:// jdih.setjen.kemendagri.go.id/files/ KAB_SUBANG_7_2001.pdf

Local Government Regulation Number 1 of 2014 concerning rock and non-metal mineral mining business (Peraturan Daerah Nomor 1 Tahun 2014 tentang usaha pertambangan mineral bukan logam dan batuan). Retrieved from https://peraturan.bpk.go.id/Home/ Details/62084/perda-kab-subang-no-1tahun-2014

Local Government Regulation Number 6 of 2016 concerning the formation and arrangement of regional apparatus of West Java Province (Peraturan Daerah Nomor 6 Tahun 2016 tentang pembentukan dan susunan perangkat daerah Provinsi Jawa Barat). Retrieved from http://bappeda.jabarprov.go.id/wpcontent/uploads/2017/o3/Perda-No-6-
Tahun-2016-Tentang-Pembentukan-dan -Susunan-Perangkat-Daerah-ProvinsiJawa-Barat.pdf

Local Government Regulation Number 2 of 2017 concerning management of mineral and coal mining (Peraturan Daerah Nomor 2 Tahun 2017 tentang pengelolaan pertambangan mineral dan batubara). Retrieved from http:// jdih.jabarprov.go.id/assets/uploads/ files/produk/30_Perda\%202\% 20Tahun\%202017.pdf

Mandala, E., Setyadiharja, R., Jefri, J., Renaldi, R., \& Mulyani, N. (2016). Implementasi kebijakan penerbitan urat Persetujuan Berlayar (SPB). Jurmal Ilmu Pemerintahan, 1(2), 249-269.

Mantoro, T. B. (2012, Desember Edisi XIV). Menyikapi Kegiatan Pertambangan di Indonesia. Warta Minerba, 1-42.

Mina, R. (2016). Desentralisasi Perlindungan dan Pengelolaan Lingkungan Hidup sebagai alternatif penyelesaian permasalahan lingkungan hidup. Jurnal Arena Hukum, 9(2), 149-165. doi: 10.21776/ ub.arenahukum.2016.00902.1

Muluk, M. R. K. (2006). Desentralisasi pemerintahan daerah. Jakarta: Bayumedia.

Prasojo, E. (2006). Desentralisasi \& pemerintah daerah: Antara model demokrasi lokal \& efisiensi struktural. Depok: Departemen Ilmu Administrasi Press, Universitas Indonesia.

Presidential Regulation Number 58 of 2017 concerning Amendment to Presidential Regulation Number 3 of 2016 concerning Acceleration of National Strategic Projects Implementation (Peraturan Presiden Nomor 58 tahun 2017 tentang Perubahan Atas Peraturan Presiden Nomor 3 Tahun 2016 tentang Percepatan Pelaksanaan Proyek Strategis Nasional). Retrieved from https:// sipuu.setkab.go.id/PUUdoc/175250/ Peraturan\%20Presiden\%2oNomor\% 2058\%20Tahun\%202017.pdf

Ripai, A. (2018, Maret 19). Inilah Lokasi 8 galian C Liar yang Ditengarai Berkontribusi Pada Pengerusakan Lingkungan di Subang. www.buanaindonesia.co.id. Re- 
trieved from https://

buanaindonesia.co.id/jabar/inilah-

lokasi-8-galian-c-liar-yang-ditengarai-

berkontribusi-pada-pengrusakan-

lingkungan-di-subang/

Ripley, R. B., \& Franklin, G. A. (1986). Policy implementation and bureaucracy. Chicago: Dorsey Press.

Risal, S. (2017). Pengelolaan Sumber Daya Alam di Era Desentralisasi. Jurnal Ilmiah Manajemen Publik dan Kebijakan Sosial, 1(2). 122-132. doi: 10.25139/ jmnegara.v1i2.792

Rumengan, J., Karamoy, H., \& Pusung, R. (2015). Efektivitas pajak pengambilan dan pengolahan bahan galian mineral bukan logam dan batuan di Kabupaten Minahasa Selatan. Jurmal EMBA, 3(4), 509-517.

Sitinjak, P. (2019, Mei 30). Tata cara pemberian izin usaha pertambangan batuan. Retrieved from http:// www.esdm.go.id

Sugiyono. (2005). Metode penelitian kuantitatif kualitatif dan R\&D. Bandung: Alfabeta.

Suhartono, S. (2013). Desentralisasi pengelolaan sumber daya alam untuk mewujudkan kesejahteraan masyarakat. Jurnal Ilmu Hukum, 9(18), 110-121. doi: 10.30996/dih.v9i18.278

Widayati, S., Usman, D. N., \& Sriyanti. (2014). Ekonomi lokal sebagai bagian dari pengembangan wilayah pertambangan yang berdampak terhadap pendapatan daerah (Studi kasus pertambangan pasir dan batuan Kab. Bandung Barat). Prosiding SNaPP: Sains, Teknologi, 4(1), 499-504.

West Java Governor Regulation Number 62 of 2016 concerning main tasks, functions, unit task details and work procedures of DPMPTSP (Peraturan Gubernur Jawa Barat Nomor 62 Tahun 2016 tentang tugas pokok, fungsi, rincian tugas unit dan tata kerja DPMPTSP). Retrieved from https:// dpmptsp.jabarprov.go.id/web/pages/ detail/63-tentang-dinas-pmptspprovinsi-jawa-barat/89 